\title{
DETERMINATION PARAMETERS OF GEOTHERMAL HEAT-EXCHANGERS FOR BIOLOGICAL TREATMENT FACILITIES \\ ${ }^{1}$ Chepak O. P., ' Kostenko V.K., 'Zavialova O.L., ' Tavrel M.I. \\ ${ }^{1}$ Donetsk National Technical University MES of Ukraine
}

\author{
ВИЗНАЧЕННЯ ПАРАМЕТРІВ ГЕОТЕРМАЛЬНИХ ТЕПЛООБМІННИКІВ ДЛЯ \\ БІООЧИСНИХ СПОРУД \\ 'Чепак О.П., ' Костенко В.К., 'Зав'ялова О.Л., 'Таврель М.І. \\ ${ }^{1}$ Донеикий национальный технический университет МОН Украинь
}

\section{ОПРЕДЕЛЕНИЕ ПАРАМЕТРОВ ГЕОТЕРМАЛЬНЫХ ТЕПЛООБМЕННИКОВ ДЛЯ БИООЧИСТНЫХ СООРУЖЕНИЙ \\ 'Чепак О.П., ' 'Костенко В.К., 'Завьялова Е.Л, 'Таврель М.И.}

${ }^{1}$ Донеикий национальный технический университет МОН Украины

\begin{abstract}
To develop methods for calculating thermo-dynamic parameters for geothermal heat-exchangers in the biological treatment facilities and other systems operating on subsoil energy basing on established laws of heat exchange between the rock mass and aquatic environment in the borehole geothermal heat exchangers. Complex approach consisting of analysis of literature sources on issues of heat-and-mass transfer for the heat situation control in treatment facilities; theoretical researches of heat transfer from the rock mass to heat carriers in the borehole geothermal heat exchangers; calculation and analytical method for determining key parameters of technology for intensive restoration of biological diversity of areas disturbed by mining operations with simultaneous purification of quarry waters. The methods are developed for theoretical determination of technical parameters for geothermal heat exchangers used in biological sewage treatment. Laws of heat exchange between the rock mass and aquatic environment are established for the cases when geothermal heat exchangers are used in biological treatment facilities, which have allowed determining key parameters for the heat exchanger including the number of boreholes and their depths for keeping $10^{\circ} \mathrm{C}$ temperature in winter time. Understanding of mechanism of heat exchange between the rock mass and aquatic environment in geothermal heat exchangers was further developed. The methods for determining quantitative parameters for geothermal heat exchangers used in treatment facilities were improved. The method is proposed for increase heat output by more than 5 times and shortening the borehole length by 1.7 times thanks to the heattransferring layer between the walls of casing pipes and the rock mass. The all-year round control of the required water temperature in biological treatment facilities will provide comfortable conditions for vital functions of hydrobionts and, therefore, dependence of sewage treatment on climatic factors will be decreased.
\end{abstract}

Keywords: geothermal energy, borehole heat-exchanger, heat transfer, heat conduction coefficient, clay and graphite mix.

\section{The problem and its connection with topical scientific and practical tasks}

At the present time there are some ecological problems in the minerals industry. One of them is to restore the biodiversity at territories with anthropogenic damages due to opencast minerals extraction, and at production areas of mines subject to liquidation, or exhausted boreholes.

After the mining of minerals using the opencast method the worked-out area looks like a lifeless landscape with its hollows free of any fertile soil layer and destructionprone edges. Both flora and fauna self-recovery of such territories would cover several centuries or even appear impossible. In this connection the most urgent approach is to look for intensification technologies in the environment formation suitable for flora and fauna development on the territories. 
Analysis results of recent studies and published works. In this respect the method is proposed allowing restoration acceleration of biological diversity in worked-out areas of opencasts through purification of water and hydrosphere on the ground of the year-round control of opencast water flows using the geothermal energy [1]. Its means the channels network formation inhabited by hydrocoles on the areas damaged through opencast mining. In the course of movement along these channels water is being clarified and desalinated due to suspensions retention by plants' root systems with absorption of dissolved substance for hydrocoles' cellular structures formation. The main idea of the low-cost phyto-technology is the use of natural elements of river protection against pollution and those of water purification using solar energy for their functioning, and requiring no service [2]. Such elements include, first of all, the highest aquatic vegetations like cane, reed, reed mace, pondweed, sweet flag, etc.

The problem side of such technology is associated with operation of phytotechnology structures in winter months. To avoid the water purification effectiveness drop in winter one should maintain water temperature within the treatment facility between 10 and $12{ }^{\circ} \mathrm{C}$.

For water purification during twelve months wells drilling is proposed with pipein-pipe well collector situated inside. Water from water bearing stratum gets into the space between the pipes and moves downwards due to the velocity pressure. In the course of its movement the heat exchange is taking place between the wall of a metal pipe with the enclosing strata temperature and water flow, and the water temperature is getting increased correspondingly. In the lower part of the pipe, due to velocity pressure and densities difference between heated and cold water, the flow changes its direction by $180^{\circ}$, and climbs up the inside plastic pipe till the surface.

The necessary temperature of water in bio-treatment facilities the whole year round is to prevent frost penetration of shallow water streams and provide the all-year purification of water and air.

Problem statement. The purpose of the work is to develop calculation methods for thermo-dynamic parameters of geothermal heat-exchangers used in biological treatment facilities and other installations using the subsoil energy on the ground of the heat exchange regularities' discovery between rock mass and aquatic environment in well geothermal heat exchangers.

Research results. To determine the parameters of temperature stabilization technology in the biological treatment facilities the corresponding heat and hydraulic calculation is done.

A coaxial heat exchanger (Fig. 1) is a steel cylinder of diameter $D$ with a closed bottom that is put into a drilled well of $h$ depth. As a rule, the role of such cylinder is played by the well's casing pipe. This cylinder coaxially contains a pipe of material with the low coefficient of heat conduction (for example, made of foamed plastic) of $d$ diameter with an open bottom. Water comes from the surface with $T_{1}$ temperature through a ring-shaped channel between the cylinder and the pipe. In the course of its movement downwards it gains the temperature close to that of rock mass $T_{2}$ due to heat exchange. Then it moves upwards within the inside pipe to the surface of the 
earth. The pipe manufactured of a heat insulating material prevents the heat exchange between water coming from the surface and that coming out of the heat exchanger. Certainly, in cold moths surrounding strata in some depths from the surface will be colder than water that would lead to the leak of heat into the heat insulation of a steel case mouth. In order to improve the heat exchange on the rest part of the collector's length the space between the well's wall and the cylinder surface must be filled with the substance its heat conduction being higher than that of enclosing strata.

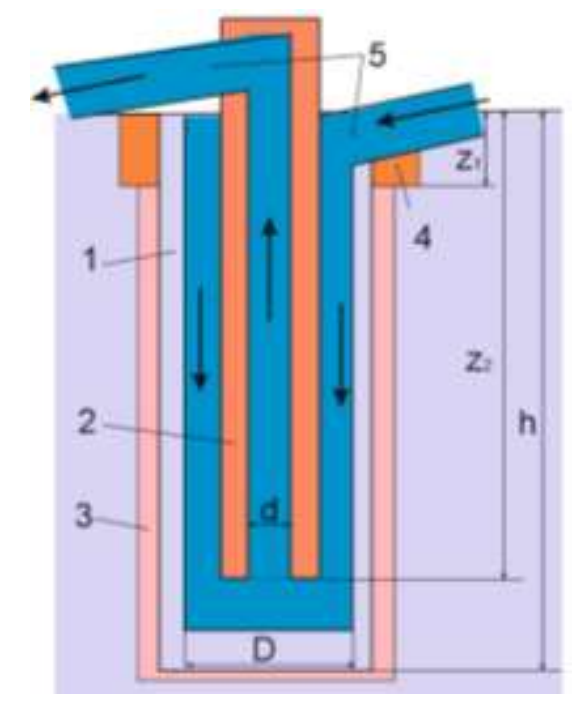

1- metal cylinder; 2 - inside pipe made of heat insulating material; 3 - the layer of material with high heat conduction; 4 -near-surface heat insulation; 5 - branches for water supply and removal; $h$-well depth; $z_{1}$ - near-surface heat insulation thickness; $z_{2}$-inside pipe depth

Figure 1 - Construction diagram of a geothermal well

The following tolerances are accepted for further heat calculation:

a) the heat exchange through the inside pipe walls shall be ignored as we consider water temperature inside to be constant $\left(T_{2}=\right.$ const);

b) the temperature of the outside well surface is constant and equal to that of rock mass $T_{\mathrm{I}}$, corresponding to the depth of well's bottom;

c) the temperature of rock mass is constant being restored with thermal energy.

In accordance with the abovementioned tolerances the task of the heat exchange is of stationery character. If we select an elementary sector $d z$ in the ring-shaped channel the quantity of heat coming to water via this ring clearance is:

$$
d Q=\pi D k\left(T_{\mathrm{g}}-T\right) d z
$$

where $k$ - is coefficient of mass to water heat transfer $W /\left(m^{2} \cdot K\right) ; T=T(z)-$ is current temperature of water moving through the ring-shaped channel, $\mathrm{K}$.

The same quantity of heat is carried out by water:

$$
d Q=c M d T,
$$

where $M$ - water flow, $\mathrm{kg} / \mathrm{sec} ; \mathrm{c}$ - specific water heat, $\mathrm{J} / \mathrm{kg} \cdot \mathrm{K}$ 


$$
M=\frac{\pi}{4}\left(D^{2}-d^{2}\right) \rho v,
$$

where $\rho$ - density of water, $\mathrm{kg} / \mathrm{m}^{3} ; v$ - velocity of water flow through the annular space, $\mathrm{m} / \mathrm{sec}$.

Comparison of (1) and (2) results in the following:

$$
d T=\frac{\pi D k}{M}\left(T_{\Gamma}-T\right) d z
$$

It is known from geophysics that ground temperature changes according to the linear law:

$$
T_{\mathrm{r}}=T_{g 0}+\operatorname{grad} T_{\mathrm{g}} z
$$

where $T_{g 0}$ ground surface temperature, $K ; \operatorname{grad} T_{g}-$ is geothermal stage of the rock mass, $K / m ; z$-distance from the ground surface, $m ; z>z_{1}-$ depth to which the ground temperature remains constant (in conditions of Donbass region $z_{l}=15 \mathrm{~m} ; T_{\mathrm{g}}=T_{\mathrm{g} 0}$ ).

Let's define system $A=\frac{\pi D k}{M c}$, after substitution we get:

$$
\begin{array}{r}
d T=A\left(T_{g 0}+\operatorname{grad} T g-T\right) d z, \\
\frac{d T}{d z}+A T=A\left(T_{g 0}+\operatorname{grad} T g z\right) .
\end{array}
$$

Nonlinear differential equation is obtained with the right side of the following appearance:

$$
y^{\prime}+P(z) y=Q(z)
$$

where $y=T ; P(z)=A ; Q(z)=A\left(T_{g 0}+\operatorname{grad} T_{\mathrm{g}} z\right)$.

Its solution is represented as follows:

$$
y=e^{-\int P d z}\left(\int Q e^{\int P d z} d z+C\right),
$$

where $C$ is integration constant.

In this case the solution looks as follows:

$$
T=e^{-\int A d z}\left(\int \frac{A}{T_{g 0}}+\operatorname{grad} T_{\mathrm{g}} z\right) e^{\int A d z} d z+C .
$$

Considering that $\int A d z=A z$ we have:

$$
T=T_{g 0}+\frac{\operatorname{grad} T_{\mathrm{g}}}{A}(A z-1)+C e^{-A z} .
$$

In border conditions: for $z=z_{1}, T=T_{1}$ we determine the integration constant: where $T_{1}-$ is temperature of water in the input to the heat exchanger, 


$$
C=\left(T_{1}-T_{g 0}-\frac{\operatorname{grad} T_{\mathrm{g}}}{A}\left(A z_{1}-1\right)\right) e^{-A z_{1}}
$$

Consequently, the current temperature of the water being heatedis to be determined from the following:

$$
T=T_{g 0}+\frac{\operatorname{grad} T_{\mathrm{g}}}{A}(A z-1)+\left(T_{1}-T_{g 0} \frac{\operatorname{grad} T_{\mathrm{g}}}{A}\left(A z_{1}-1\right)\right) e^{-A\left(z_{1}-z\right)} .
$$

The insulation depth of the well mouth is determined from the condition of temperatures equality for mass and water: at

$$
\begin{gathered}
z=z_{1} T_{1}=T_{g 0}+\left(\operatorname{grad} T_{\mathrm{g}}\right) z_{1} ; \\
z_{1}=\frac{T_{1}-T_{g 0}}{\operatorname{grad} T_{\mathrm{g}}} .
\end{gathered}
$$

Considering the necessary temperature of the output water $T=T_{2}$ we can determine the required length of the inside pipe $\mathrm{z}_{2}$ solving a implicit equation:

$$
T_{2}=T_{g 0}+\frac{\operatorname{grad} T_{\mathrm{g}}}{A}\left(A z_{2}-1\right)+\left(T_{1}-T_{g 0} \frac{\operatorname{grad} T_{\mathrm{g}}}{A}\left(A z_{1}-1\right)\right) e^{-A\left(z_{1}-z_{2}\right)} .
$$

To avoid heat losses and water temperature decrease in the sector $0<z \leq z_{1}$ where $T_{1}>T_{g}$ the heat insulation is required for the well mouth. The insulation parameters are calculated as follows.

Using reference literature, we determine physical parameters of waterfor $T_{1}=$ const: density $\rho_{1}$; heat capacity $C_{\rho 1}$; coefficient of thermal conduction $\lambda_{1}$; water flow rate $v_{1}$; and $\operatorname{Pr}_{1}$ where $\operatorname{Pr}_{1}$ is Prandtl number.

When water consumption equals to $M$ its flow rate in the ring channel is:

$$
v_{1}=\frac{4 M}{\operatorname{Pr}_{1} \pi\left(D^{2}-d^{2}\right)},
$$

while Reynolds number is:

$$
\operatorname{Re}=\frac{v_{1} d_{e}}{v_{1}}
$$

where $d_{\mathrm{e}}=D-d-$ is the equivalent channel diameter, $\mathrm{m}$.

The average mass temperature in the sector is:

$$
\overline{\mathrm{T}}_{\Gamma}=\frac{1}{z_{1}} \int_{0}^{z_{1}}\left(T_{g 0}+\operatorname{grad} T_{\mathrm{r}} z\right) d z=T_{g 0}+\frac{\operatorname{grad} T_{\mathrm{g}}}{2} z_{1} .
$$

We consider the temperature of the steel cylinder's wall as $T_{c}=\overline{\mathrm{T}}_{\Gamma}$. Using 
reference literature, we determine the coefficient of thermal conduction $\lambda_{c}$ for the cylinder material (steel) under such temperature [Vargaftik, N.B., 1972], and Prandtl number [Rivkin, S.L., Aleksandrov, A.A., 1980].

Nusselt number and coefficient of heat transfer from water to the cylinder wall [Petrichenko, R.M., Petrichenko, M.R., 1979] is as follows:

$$
\begin{gathered}
\mathrm{Nu}_{1}=0,021 \mathrm{Re}_{1}^{0,8} \operatorname{Pr}_{1}^{0,43}\left(\operatorname{Pr}_{1} / \operatorname{Pr}_{c}\right)^{0,25} ; \\
\alpha_{1}=\mathrm{Nu}_{1} \frac{\lambda_{1}}{d_{\mathrm{e}}}
\end{gathered}
$$

Material with coefficient of thermal conduction $\lambda_{\text {ins }}$ is accepted for insulation.

Then the coefficient of heat transfers from water to ground in the sector $0<z<z_{1}$ is:

$$
k=\frac{1}{\frac{1}{\alpha_{1}}+\frac{\delta_{c}}{\lambda_{c}}+\frac{\delta_{\mathrm{ins}}}{\lambda_{\mathrm{ins}}}},
$$

where $\delta_{\mathrm{c}}, \delta_{\mathrm{ins}}-$ is wall thickness of the steel cylinder and insulation correspondingly, $\mathrm{m} ; \lambda_{\mathrm{c}}, \lambda_{\text {ins }}-$ is thermal conduction coefficient of steel and insulation material correspondingly, $\mathrm{W} /(\mathrm{m} \cdot \mathrm{K})$.

We select insulation thickness $\delta_{\text {ins }}$ provided $k_{1} \rightarrow 0$.

The following values are taken as an example for calculation: $T_{g 0}=10,1^{\circ} \mathrm{C} ; T_{1}=7^{\circ} \mathrm{C} ; T_{2}=12{ }^{\circ} \mathrm{C} ; T_{\mathrm{g}}=15^{\circ} \mathrm{C}-$ is the average temperature of enclosing rocks; $D=100 \mathrm{~mm} ; d=50 \mathrm{~mm} ; \rho=\rho_{\mathrm{w}}=1000 \mathrm{~kg} / \mathrm{m}^{3}$ is water density; $c=c_{p \mathrm{w}}=4.187$ $\mathrm{kJ} /(\mathrm{kj} \cdot \mathrm{K})$ is specific thermal capacity of water for constant pressure; $\operatorname{grad} T_{g}=1 / 33$ $=0.0303 \mathrm{~K} / \mathrm{m}$; heat insulation (foamed glass) layer thickness in the sector $0<z<z_{1}$ is $\delta_{\text {ins }}=0.02 m ; \lambda_{\text {ins }}=0.47 \mathrm{~W} /(\mathrm{m} \cdot K)$; the steel cylinder wall thickness $\delta_{\mathrm{c}}=0.03 \mathrm{~m}$; $\lambda_{\mathrm{c}}=24.4 \mathrm{~W} /(\mathrm{m} \cdot \mathrm{K})$ (stainless steel $4 \mathrm{X} 13$ ); coefficient of heat transfer fromthe case inside wall to water $\alpha_{2}=4652 \mathrm{~W} /(\mathrm{m} \cdot \mathrm{K})$

In accordance with formula (22) coefficient of heat transfer from ground to water in the sector $0<z<z_{1}$ equals to $22.7 \mathrm{~W} /\left(\mathrm{m}^{2} \cdot K\right)$.

In the sector $z_{1}<z<z_{2}$ the space between the outside cylinder wall and mass is filled with clay and graphite mix the mass fraction of graphite being $50 \%$, and thickness $\delta_{\mathrm{gg}}=10 \mathrm{~mm}$ [3]. Then the mix coefficient of thermal conduction $\lambda_{\mathrm{gg}}=15.8 \mathrm{~W} /(\mathrm{m} \cdot \mathrm{K})$ while heat transfer one $k_{2}=483 \mathrm{~W} /\left(\mathrm{m}^{2} \cdot \mathrm{K}\right)$.

The case of water purification at Balka Mokraya Open Pit of Heidelberg Cement Ukraine PJSC is considered as an example. The average daily inflow of water to the open pit is $Q=660 \mathrm{~m}^{3} /$ day. Water having initial temperature of $T_{1}=7{ }^{\circ} \mathrm{C}$ moves by gravity in the pit bottom. In winter its part is heated in geothermal wells up to the temperature of $T_{2}=12^{\circ} \mathrm{C}$. In general, after mixing in the pit water is heated up to the temperature of $T_{a v}=10^{\circ} \mathrm{C}$.

The required flow rate of the water flowing through the wells can be calculated as follows: 


$$
\begin{gathered}
Q T_{a v}=Q_{1} \mathrm{~T}_{2}+\left(Q-Q_{1}\right) T_{1} \\
Q_{1}=Q\left(T_{a v} T_{1}\right) / T_{2}=396 \mathrm{~m}^{3} / \text { day. }
\end{gathered}
$$

Assumed that the number of wells is $\mathrm{N}=24$, the flow rate through one well will be $\mathrm{q}=16,6 \mathrm{~m}^{3} /$ day $=2,92 \cdot 10-4 \mathrm{~m}^{3} / \mathrm{sec}$., and mass flow will be $\mathrm{M}=0,192 \mathrm{~kg} / \mathrm{sec}$. For the complex $A_{1}=8.9 \cdot 10^{-3}$ and $A_{2}=0.189$ (see expression (6)) calculations on equations (15) and (16) of these values are represented in the Table 1.

Table 1- Water temperature changes along the well depth using heat conducting material

\begin{tabular}{|c|c|c|c|c|c|c|c|c|c|c|c|}
\hline$Z, \mathrm{~m}$ & 0 & 25 & 50 & 75 & 100 & 125 & 150 & 175 & 200 & 225 & 250 \\
\hline$T,{ }^{\circ} \mathrm{C}$ & 7 & 10,67 & 11,45 & 12,21 & 12,97 & 13,73 & 14,48 & 15,24 & 15,99 & 16,76 & 17,51 \\
\hline
\end{tabular}

Besides, calculation of water temperature changes along the well depth was done for the absence of heat conducting material. The heat exchanger's steel case contacts with the mixture of sandstones and argillites: $\lambda^{\prime}=3.4 \mathrm{~W} /(\mathrm{m} \cdot \mathrm{K})$ andwater: $\lambda^{\prime \prime}=0.59$ $W /(m \cdot K)$. In this case coefficient of heat transfer from ground to water equals to $k$ $=43.5 \mathrm{~W} /\left(\mathrm{m}^{2} \cdot K\right)$, and complex $A=0.017$.

Consequently, to heat water to the same temperature using heat conducting material as the filler of the space behind the pipes the well shall be 1.7 times shorter than for the direct contact between the steel case and enclosing rocks (Fig. 2)

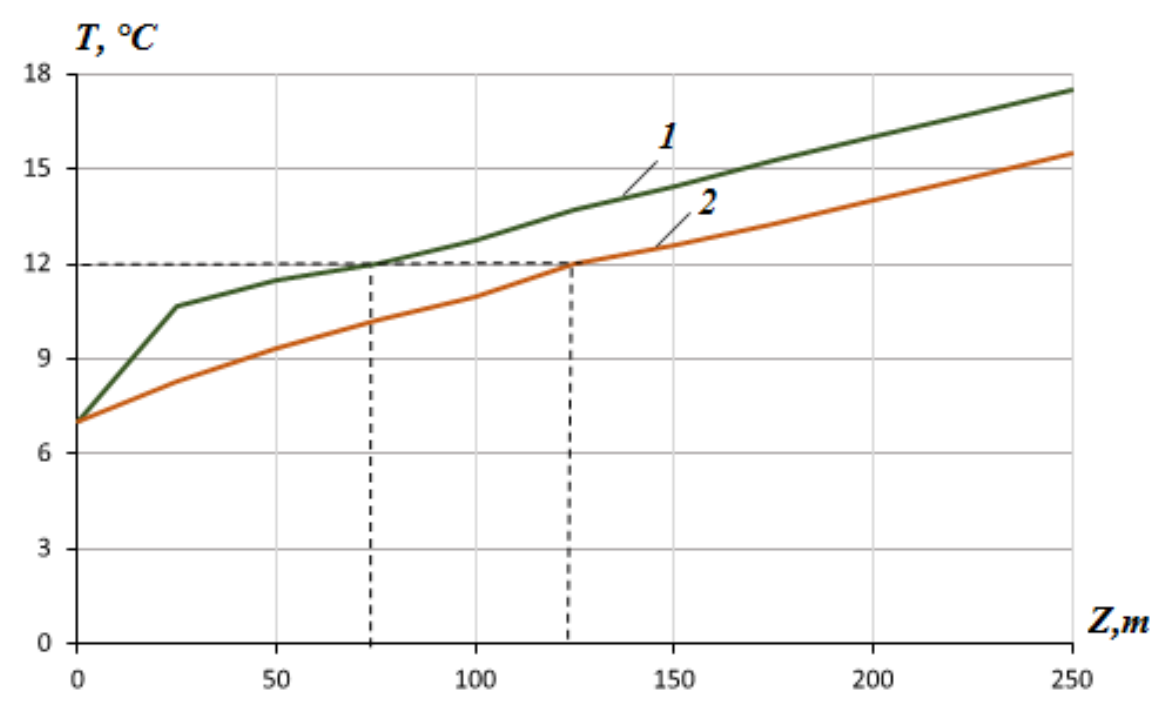

Figure 2 - Variations of water temperature depending on well depth with (1) and without (2) clay and graphite mixture

According to the calculations made, to heat the water with flow rate of 660 $\mathrm{m}^{3} /$ day up to $10^{\circ} \mathrm{C}$ using geothermal energy there should be 24 geothermal wells drilled with diameter of $200 \mathrm{~mm}$ and depth of $76 \mathrm{~m}$. The wells should be insulated with $20 \mathrm{~mm}$ foam glass to the depth of $25 \mathrm{~mm}$, then a 4X13 steel shell with $20 \mathrm{~mm}$ wall should be installed with coaxially inserted plastic pipe inside having diameter of $50 \mathrm{~mm}$ and length of $75 \mathrm{~m}$. The space between the shell and the rock mass in the section from 25 to $75 \mathrm{~m}$ is filled with clay and graphite mixture with graphite content of $50 \%$ by weight. 
In this way, the water flow of $396 \mathrm{~m}^{3} /$ day will flow through the wells. The water temperature at the outlet will be $12{ }^{\circ} \mathrm{C}$. Mixing with the rest of water will raise the water temperature in the quarry up to $10^{\circ} \mathrm{C}$.

Conclusions. The established regularities of thermal exchange between rock mass and aquatic environment with the geothermal heat exchangers application for biological treatment facilities allowed determination of its basic parameters including wells number and depths for $10^{\circ} \mathrm{C}$ temperature maintenance in winter.

As a consequence, maintenance of the required temperature of water in the biopurifier would provide comfortable conditions for vital functions of hydrocoles during the whole year; prevent frost penetration in shallow water flows and death of algae and mollusks in winter period; improve conditions for vital functions of hydrocoles in summer period due to water cooling in shallow part of the pit. The water resource in the treatment structure shall perform the whole-year function of environment purification due to solution of carbon dioxide and other gases followed by their fixation by plants for their cells formation and nutrition. The non-freezing water reservoir could be used as the hibernation place for swimming birds. The abovementioned would contribute in the restoration of biologic diversity in workedout areas of opencast mining.

\section{REFERENCES}

1. Kostenko V., Zavyalova E. L. and Chepak O. P. (2014), "The restoration of biodiversity in mined-out spaces quarries", Proc. of the international forum-competition of young scientists "Problems of subsoil use", Saint-Petersburg, pp. 131-133.

2. Stol'berg F. V. (2011), "Low-cost technologies for the ecological restoration of small rivers of Ukraine», Naukovo-tekhnichnyy zbirnyk " Komunalne hospodarstvo mist", vol. 99, pp.253-266.

3. Kostenko V. K., Zavyalova O. L., Box I. V., Spinules O. S., Chepak O. P. and Filatov, I. Yu. Donetsk National Technical University (2014), Sposib vidobuvannya geotermalnogo tepla [Method of geothermal heat extraction] State Register of Patents of Ukraine, Kiev, UA, Pat. № 91730

\section{СПИСОК ЛІТЕРАТУРИ}

1. Костенко В.К., Завьялова Е.Л., Чепак О.П. Восстановление биологического разнообразия в выработанных пространствах карьеров/ // Проблемы недропользования: междунар. форум-конкурс молодых ученых, 23-25 апреля 2014 г.: сборник науч. тр. Часть II. Санкт-Петербург, 2014. С. 131 - 133.

2. Стольберг В.Ф. Малозатратные технологии для экологичнского восстановления малых рек Украины // Науковотехнічний збірник "Комунальне господарство міст". 2011. № 99. С. 253-266.

3. Патент на корисну модель № 91730 UA, MПК F24J3/08. Спосіб видобування геотермального тепла / В.К. Костенко, О.Л. Зав'ялова, І.В.Скринецька, О.С. Шипика, О. П. Чепак, Ю. І. Філатов; заявник і власник ДонНТУ. - и2014 02110.

\section{About the author}

Chepak Olga Petrivna, Doctoral Student in the Department of Nature and Environmental Activity, Donetsk National Technical University MES of Ukraine, Pokrovsk, Donetsk Region, Ukraine, olha.chepak@donntu.edu.ua

Kostenko Viktor Klimentovych, Doctor of Technical Sciences (D. Sc.), Professor, Head of the Department of Nature and Environmental Activity, Donetsk National Technical University MES of Ukraine, Pokrovsk, Donetsk Region, Ukraine, vk.kostenko@gmail.com

Zavialova Olena Leonidivna, Candidate of Technical .Sciences (Ph. D.), Associate Professor, Associate Professor in the Department of Nature and Environmental Activity, Donetsk National Technical University MES of Ukraine, Pokrovsk, Donetsk Region, Ukraine, elenazavialova@rambler.ru

Tavrel Maryna Ihorivna, Doctoral Student in the Department of Nature and Environmental Activity, Donetsk National Technical University MES of Ukraine, Pokrovsk, Donetsk Region, Ukraine, maryna.tavrel@donntu.edu.ua

\section{Про авторів}

Чепак Ольга Петрівна, аспірант кафедри природоохоронної діяльності, Донецький національний технічний університет МОН України, Покровськ Донецької обл., Україна, olha.chepak@donntu.edu.uа

Костенко Віктор Климентович, доктор технічних наук, профресор, завідувач кафедри природоохоронної діяльності, Донецький національний технічний університет МОН Україны, Покровськ Донецкої обл., Україна, vk.kostenko@gmail.com

Зав'ялова Олена Леонідівна, кандидат технічних наук, доцент, доцент кафедри природоохоронної діяльності, 
Донецький національний технічний університет МОН України, Покровськ Донецької обл., Україна, elenazavialova@rambler.ru

Таврель Марина Іеорівна, аспірант кафедри природоохоронної діяльності, Донецький національний технічний університет МОН України, Покровськ Донецької обл., Україна, maryna.tavrel@donntu.edu.ua

Анотація. Розробка методики розрахунку термодинамічних параметрів геотермальних теплообмінників, використовуваних в біоочистних спорудах та інших установках, що використовують енергію надр на основі розкриття закономірностей теплообміну між породним масивом і водним середовищем в свердловинних геотермальних теплообмінниках. Комплексний підхід, що включає аналіз літературних джерел, присвячених питанням тепломасопереносу при регулюванні теплової обстановки в очисних спорудах, теоретичні дослідження переносу теплоти від породного масиву до теплоносія в свердловинному геотермальному теплообміннику, розрахунково-аналітичний метод при визначенні основних параметрів технології інтенсивного відновлення біологічного різноманіття на техногенно порушених територіях з одночасним очищенням кар'єрних вод. Розроблено методику теоретичного визначення технічних параметрів геотермальних теплообмінників, що використовуються для біологічного очищення стоків. Встановлені закономірності теплообміну між породним масивом і водним середовищем при використанні геотермальних теплообмінників в біоочисному споруді, які дозволили визначити його основні параметри (кількість свердловин і їх глибину) для підтримки температури $10^{\circ} \mathrm{C}$ в зимовий період. Отримало подальший розвиток уявлення про механізм теплообміну між порідним масивом і водним середовищем в геотермальних теплообмінниках. Удосконалено методику визначення кількісних параметрів геотермальних теплообмінників для очисних споруд. Запропоновано спосіб збільшення питомого теплос'єма більш ніж в 5 разів і зменшення глибини свердловини в 1,7 рази за рахунок застосування теплопровідного шару між стінкою обсадної труби і породним масивом. Цілорічне регулювання необхідної температури води в біоочистном спорудженні створить комфортні умови для життєдіяльності гідробіонтів і таким чином знизиться залежність ефективності очищення стоків від кліматичних фракторів.

Ключові слова: геотермальна енергія, теплообмінник свердловинний, теплопередача, коефіцієнт теплопровідності, глинографитна суміш.

Аннотация. Разработка методики расчета термодинамических параметров геотермальных теплообменников, используемых в биоочистных сооружениях и других установках, использующих энергию недр, на основании раскрытия закономерностей теплообмена между породным массивом и водной средой в скважинных геотермальных теплообменниках. Комплексный подход, включающий анализ литературных источников, посвященных вопросам тепломассопереноса при регулировании тепловой обстановки в очистных сооружениях, теоретические исследования переноса теплоты от породного массива к теплоносителю в скважинном геотермальном теплообменнике, расчетно-аналитический метод при определении основных параметров технологии интенсивного восстановления биологического разнообразия на техногенно нарушенных территориях с одновременной очисткой карьерных вод. Разработана методика теоретического определения технических параметров геотермальных теплообменников, применяемых для биологической очистки стоков. Установлены закономерности теплообмена между породным массивом и водной средой при использовании геотермальных теплообменников в биоочистном сооружении, которые позволили определить его основные параметры (количество скважин и их глубину) для поддержания температуры $10^{\circ} \mathrm{C}$ в зимний период. Получило дальнейшее развитие представление о механизме теплообмена между породным массивом и водной средой в геотермальных теплообменниках. Усовершенствована методика определения количественных параметров геотермальных теплообменников для очистных сооружений. Предложен способ увеличения удельного теплосъема более чем в 5 раз и уменьшения глубины скважины в 1,7 раза за счет применения теплопроводящего слоя между стенкой обсадной трубы и породным массивом. Круглогодичное регулирования необходимой температуры воды в биоочистном сооружении создаст комфортные условия для жизнедеятельности гидробионтов и таким образом снизится зависимость эфффективности очистки стоков от климатических факторов.

Ключевые слова: геотермальная энергия, теплообменник скважинный, теплопередача, коэфффициент теплопроводности, глинографитная смесь.

Стаття надійшла до редакції 4.07. 2018

Рекомендовано до друку д-ром техн. наук Т.В. Бунько 